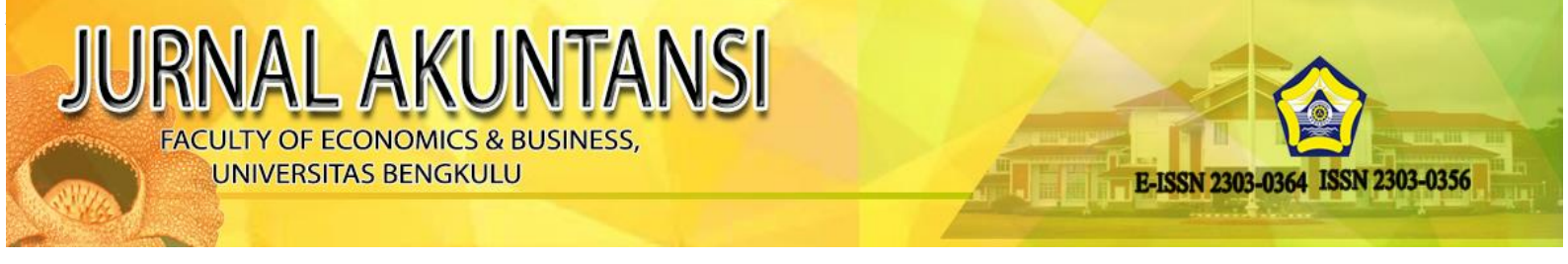

\title{
DIVERSITAS MANAJEMEN DAN DIVERSIFIKASI PENDAPATAN SEBAGAI FAKTOR YANG MEMPENGARUHI PROFITABILITAS PERBANKAN (Studi Empiris Pada Perbankan yang Terdaftar di BEI Periode 2010 - 2014)
}

\author{
Sayydatuz Shoimah Jamruddin ${ }^{1)}$, Nova Novita ${ }^{2)}$ \\ nova.novita@ibs.ac.id $\left.{ }^{2}\right)$ \\ STIE Indonesia Banking School
}

\begin{abstract}
Ideally, there is no difference perception between members of an organization toward internal auditor roles. This study identified the perception between employees and lecturers of University of Bengkulu; whether the internal auditor as audit snoop, consultant, or Management representative. Data is analyzed using independent sample $t$ test. The research results show that there are difference perceptions between employee and lecturers toward the role of internal auditor as audit snoop and as a consultant. However, this study found no difference perceptions among them on the role of internal auditor as management's representative. Major role of internal auditor according to employee and lecturers at the University of Bengkulu is the role of as a consultant.
\end{abstract}

Keywords : Internal Auditor, Role, Audit Snoop, Consultant, Management's Representative.

\section{PENDAHULUAN}

Auditor internal dibentuk dalam rangka menguji dan mengevaluasi kegiatan-kegiatan bagi organisasi untuk membantu pecapaian efektifitas organisasi serta menyediakan sarana analisis, penilaian, rekomendasi, nasihat, dan informasi sehubungan dengan aktifitas yang diaudit dalam organisasi. Tanpa adanya fungsi auditor internal, pimpina kesulitan untuk memperoleh informasi internal yang bebas mengenai kinerja organisasi.

Di dalam menjalankan fungsinya, auditor yang melaksanakan proses audit di organisasi tidak hanya berasal dari pihak eksternal organisasi saja, namun juga dapat dilakukan oleh pihak internal organisasi. Menurut Mulyadi (2013:28) orang atau kelompok orang yang melaksanakan audit dapat dikelompokkan menjadi tiga golongan: auditor independen, auditor pemerintah, dan auditor intern. Perusahaan mempekerjakan auditor internal mereka sendiri, baik untuk melakukan audit keuangan maupun operasional. Oleh karena auditor internal menghabiskan waktu mereka dalam suatu organisasi, maka mereka tahu lebih banyak mengenai operasional organisasi dibandingkan auditor eksternal (Arens dkk, 2011:450).

Audit internal merupakan suatu aktivitas konsultasi yang dikelola secara independen dan objektif, yang dirancang sebagai penambah nilai untuk meningkatkan kegiatan operasional organisasi. Secara efektif, audit internal menyediakan informasi yang dibutuhkan pimpinan dalam menjalankan tanggung jawab. Penilaian secara independen dilakukan audit internal pada suatu organisasi untuk menilai kegiatan operasional dengan mengukur dan mengevaluasi kecukupan kontrol serta efektivitas dan efisiensi dari kinerja organisasi (Sawyer, 2005:7).

Pada kenyataannya, keberadaan auditor internal dipandang dari banyak sisi oleh pihak dalam organisasi. Awalny, auditor internal lebih berperan sebagai pengawas atau mata dan telinga manajemen karena manajemen membutuhkan kepastian terkait dengan pelaksanaan kebijakan yang telah ditetapkan untuk menghindari tindakan yang menyimpang. Audit internal lebih berorientasi pada pelaksanaan tindakan pemeriksaan terhadap tingkat kepatuhan 
para pelaksana dengan ketentuan-ketentuan yang ada dan ini sering dianggap sebagai tindakan yang konfrontatif (Tampubolon, 2005:1).

Dewasa ini, fokus utama audit internal mengalami pergeseran menjadi konsultan untuk organisasi atau kliennya, yaitu membantu satuan kerja operasional mengelola risiko dengan mengidentifikasi masalah-masalah dan memberikan saran untuk tindakan perbaikan yang dapat memberikan tambahan nilai sebagai amunisi memperkuat organisasi. Bahkan untuk masa yang akan datang diprediksikan peran auditor internal akan menjadi katalisator yang akan ikut serta dalam penentuan tujuan dari suatu organisasi (Tampubolon, 2005:2).

Universitas Bengkulu adalah salah satu Badan Layanan Umum (BLU) yang menjalankan usaha secara sehat. Konsekuensi dari status ini, mengharuskan Universitas Bengkulu memiliki unit pengawasan internal. Keberadaan unit ini seiring dengan umur status BLU yag disandang. Penelitian ini difokuskan untuk melihat persepsi seluruh pegawai yang terdiri dari tenaga pendidik dan tenaga pendidikan di Universitas Bengkulu atas peran auditor internal. Adapun variabel yang menjadi ukuran peran auditor internal dalam penilitian ini adalah Audit Snoop, Consultant, dan Management's Representative. Dengan menggunakan ukuran tersebut, diharapkan persepsi kedua tipe karyawan atas peran auditor internal adalah sama.

Menurut Ikhsan (2005:93) persepsi adalah bagaimana orang-orang melihat atau menginterpretasikan peristiwa, objek, serta manusia. Orang-orang bertindak atas dasar persepsi mereka dengan mengabaikan apakah persepsi itu mencerminkan kenyataan yang sebenarnya. Pada kenyataannya, setiap orang memiliki persepsinya sendiri atas suatu kejadian. Uraian kenyataan seseorang mungkin jauh berbeda dengan uraian orang lain. Persepsi merupakan suatu proses yang melibatkan pengetahuan-pengetahuan sebelumnya dalam memperoleh dan menginterpretasikan stimulus yang ditunjukkan oleh pancaindra. Dengan kata lain, persepsi merupakan kombinasi antara faktor utama dunia luar (stimulus visual) dan diri manusia itu sendiri (pengetahuan-pengetahuan sebelumnya).

Penelitian terdahulu yang dilakukan oleh Listiatik (2007) menyebutkan bahwa peran auditor internal menimbulkan perbedaan persepsi karyawan Rumah Sakit Panti Rini. Ada beberapa karyawan memiliki persepsi bahwa auditor internal sebagai kawan karena menganggap dengan keberadaan auditor internal sebagai konsultan dan katalisator yang dapat memberikan kontribusi berupa saran atau masukan dalam pencapaian tujuan perusahaan. Di sisi lain, ada sebagian karyawan yang memiliki persepsi bahwa auditor internal adalah lawan karena melihat peran sebagai pengawas yang dijalankan auditor internal seperti layaknya polisi yang melakukan pemeriksaan. Sama halnya dengan penelitian yang dilakukan oleh Tjahyono (2010) mengenai analisis peran auditor internal di Perguruan Tinggi Swasta Universitas Sanata Dharma menunjukkan bahwa peran auditor internal yang paling berperan adalah sebagai Consultant. Akan tetapi, berbeda dengan hasil penelitian yang dilakukan oleh Priantinah dkk (2012) di Hotel Inna Garuda Yogyakarta yang menunjukkan bahwa peran auditor yang paling berperan adalah sebagai pengawas.

Penelitian ini merujuk pada penelitian yang dilakukan Tjahyono (2010). Perbedaan dengan penelitian sebelumnya adalah responden yang digunakan dalam penelitian dan variabel yang menjadi ukuran peran auditor internal. Adapun dalam penelitian Tjahyono (2010), responden yang digunakan dalam penelitian adalah pihak Yayasan, Rektorat, Kepala Biro atau Unit, dan struktural Fakultas dan variabel untuk peran auditor internalnya adalah sebagai Watchdog, Consultant, dan Catalyst. Sedangkan responden yang digunakan dalam penelitian ini adalah Pegawai Tenaga Pendidik dan Pegawai Kependidikan dan variabel untuk peran auditor internalnya adalah sebagai Audit Snoop, consultan, Management's Representative. 


\section{KERANGKA TEORITIS DAN PENGEMBANGAN HIPOTESIS}

\section{Teori Persepsi}

Menurut Kreitner (2003:208) "Persepsi adalah proses kognitif yang memungkinkan kita dapat menafsirkan dan memahami lingkungan di sekitar kita". Penafsiran tersebut merupakan pandangan kita tentang lingkungan atau tempat di mana kita berada. Menurut Suharnan (2005: 23) persepsi adalah suatu proses penggunaan pengetahuan yang telah dimiliki (yang disimpan di dalam ingatan) untuk mendeteksi atau memperoleh dan menginterpretasi stimulus (rangsangan) yang diterima oleh alat indera seperti mata, telinga dan hidung.

Menurut Sunaryo (2004), persepsi merupakan proses diterimanya rangsangan melalui panca indera yang didahului oleh perhatian (attention), sehingga individu sadar tentang sesuatu yang ada di dalam maupun di luar dirinya. Melalui Persepsi, dapat diketahui perubahan perilaku seseorang. Setiap individu kadang-kadang memiliki persepsi yang berbeda walaupun mengamati objek yang sama.

\section{Faktor-faktor yang mempengaruhi persepsi}

Persepsi dikatakan rumit dan aktif karena walaupun persepsi merupakan pertemuan antara proses kognitif ddan kenyataan, persepsi lebih banyak melibatkan kegiatan kognitif. Persepsi lebih banyak dipengaruhi oleh kesadaran, ingatan, pikiran, dan bahasa. Dengan demikian, persepsi bukanlah cerminan yang tepat dari realitas (Ikhsan, 2010: 94).

Dari beberapa definisi persepsi, dapat disimpulkan bahwa persepsi setiap individu mengenai suatu objek atau peristiwa tergantung pada dua faktor, yaitu faktor dalam diri seseorang (aspek kogniti) dan faktor dunia luar (aspek stimulus visual). Robbins (2008: 175), mengemukakan bahwa sejumlah faktor beroperasi untuk membentuk dan terkadang mengubah persepsi, dalam diri objek atau target yang diartikan, atau dalam konteks situasi di mana persepsi tersebut dibuat.

Sedangkan menurut Robbins (2008: 46), faktor- faktor yang mempengaruhi persepsi individu, meliputi: Pertama; Faktor pelaku persepsi. Apabila seorang individu memandang suatu objek dan mencoba menafsirkan apa yang dilihatnya, penafsiran itu dipengaruhi oleh karakteristik-karakteristik pribadi dari pelaku persepsi individual itu. Kebutuhan atau motif yang tidak dipuaskan dapat merangsang individu dan dapat merupakan suatu pengaruh yang kuat pada persepsi mereka. Oleh karena kepentingan individu berbeda-beda, maka apa yang dipersepsikan oleh satu orang dalam situasi dapat berbeda dengan apa yang dipersepsikan orang lain. Faktor ini berkaitan dengan sikap, motif, kepentingan, pengalaman, dan pengharapan.

Kedua; Faktor objek. Karakteristik-karakteristik dalam target yang diamati, dapat mempengaruhi apa yang dipersepsikan. Objek atau peristiwa yang belum pernah dialami sebelumnya akan lebih mencolok dari pada yang pernah dialami masa lalu. Di samping itu, objek-objek yang berdekatan satu dengan yang lain cenderung dipersepsikan bersama-sama. Sebagai akibat dari kedekatan fisik atau waktu, sering individu menggabungkan objek-objek yang sebenarnya tidak berkaitan. Faktor objek meliputi: ukuran, intensitas dan kontras atau pertentangan. Ketiga; Faktor situasi. Tekanan waktu, sikap orang lain, lingkungan kerja, lingkungan social, dan faktor-faktor situasi lain mempengaruhi persepsi.

\section{Auditor internal}

Pemeriksa intern (Internal Auditing) adalah aktivitas penilaian yang independen untuk setiap kegiatan operasional, lini dan staf organisasi dalam perusahaan (Halim, 1992). Dalam penelitian ini penulis menggunakan istilah Pemeriksaan Intern, Pengawasan Internal, Internal 
Auditing dan Audit Internal. Istilah-istilah tersebut mempunyai arti dan maksud yang sama yaitu pemeriksaan yang dilakukan dari dalam organisasi yaitu pegawai organisasi yang bersangkutan.

Dalam melaksanakan tugasnya, audit internal tidak hanya melaksanakan pemeriksaan untuk menemukan kelemahan yang terdapat pada unit-unit yang ada apakah sudah sesuai dengan apa yang telah digariskan atau belum melainkan juga memberikan rekomendasi perbaikan-perbaikan pada setiap penyimpangan yang terjadi sehingga dapat berjalan sesuai apa yang telah ditetapkan. Tugas dari audit internal adalah membantu organisasi untuk mencapai tujuan perusahaan melalui sistem yang ditetapkan dan memastikan rencana dari perusahaan tersebut telah dijalankan serta informasi yang digunakan relevan. Demikian pula sistem pengendaliannya apakah sudah cocok dengan program organisasi serta penerapannya pada organisasi tersebut. Sedangkan fungsi audit internal adalah sebuah fungsi penilaian independen dalam suatu organisasi guna menelaah atau mempelajari dan menilai kegiatankegiatan organisasi untuk memberikan saran-saran kepada manajemen dengan tujuan untuk membantu semua tingkatan manajemen agar tanggung jawabnya dapat dilaksanakan secara efisien dan efektif (Tugiman, 1995:11).

Kegiatan audit internal menguji dan menilai efektivitas dan kecukupan sistem pengendalian internal yang ada dalam organisasi. Tanpa fungsi audit internal, pimpinan organisasi tidak memiliki sumber informasi internal yang bebas mengenai kinerja organisasi, mengingat pengertian audit internal adalah: "Internal Auditing is an independent appraisal function esthablished within an organization to examine and evaluate its activities as a service to the organization (Sawyer 2003:8)."

Redefinisi audit internal yang telah ditetapkan oleh IIA Board of Directors pada bulan juni 1999 adalah : Internal auditing is an independent, objective assurance and consulting activity designed to add value and improve an organization's operations. It helps an organization accomplish its objective by bringing a systematic, disciplined approach to evaluate and improve the effectiveness of risk management, control, and governance process". Audit tersebut membantu organisasi mencapai tujuannya dengan menerapkan pendekatan secara sistematis dan berdisiplin untuk mengevaluasi dan meningkatkan efektivitas proses pengelolaan resiko, kecukupan kontrol dan pengelolaan organisasi (Sawyer 2003:9).

\section{Peran auditor internal dalam organisasi}

Dalam sebuah organisasi fungsi manajemen berawal dari perencanaan, pengorganisasian, pengarahan dan pengendalian. Untuk menjalankan sistem pengendalian, manajer puncak dalam sebuah organisasi dibantu oleh auditor internal dalam menjalankan tugasnya dalam mengendalikan sebuah organisasi. Auditor internal adalah orang-orang yang bekerja pada organisasi untuk mengevaluasi, menilai dan memberikan saran-saran kepada manajemen organisasi tersebut. Peran auditor internal antara lain menaksir dan menghitung risiko yang akan terjadi dalam berbagai aktivitas yang terjadi dalam organisasi, melakukan tugas lain yang diminta secara khusus oleh manajemen, juga mempunyai waktu untuk konsultasi dan memecahkan masalah bila diminta oleh bagian lain dari organisasi tersebut.

Selain itu peran auditor internal menurut Tampubolon (2005:1-2) adalah sebagai berikut: Pertama, peran konvensional auditor sebagai pengawas. Pada awalnya audit internal dikenal sebagai pendekatan berbasis pada sistem yang dalam perkembangan selanjutnya beralih keaudit internal berbasiskan proses. Pada saat itu audit internal masih banyak berperan sebagai mata dan telinga menajemen dikarenakan pihak manajemen memerlukan kepastian bahwa semua kebijakan yang telah ditetapkan dapat berjalan sesuai apa yang telah digariskan atau dengan kata lain tidak akan dilaksanakan secara menyimpang juga oleh para pegawai. 
Orientasi audit internal banyak dilakukan pemeriksaan terhadap tingkat ketentuan-ketentuan yang ada atau audit kepatuhan. Peran dari fungsi pengawasini secara berangsur ditinggalkan.

Kedua, peran auditor sebagai konsultan. Dalam perkembangan audit, muncul audit berbasiskan resiko yang disebabkan karena banyak usaha yang memiliki resiko yang tinggi. Maka selain sebagai pemeriksa, audit internal berfungsi juga sebagai mitra manajemen yang berperan sebagai konsultan yang mempunyai tugas untuk memberikan masukan berbagai masalah yang berhubungan dengan sumber daya yang dimiliki dalam organisasi tersebut. Selain itu dikarenakan keterbatasan sumber daya yang tersedia maka operasional auditnya bersifat jangka menengah. Audit ini memfokuskan pada pengelolaan resiko dengan mengidentifikasi masalah serta memberikan saran-saran sebagai nilai tambah sehingga dapat memperkuat organisasi tersebut.

Ketiga, peran auditor internal sebagai katalisator. Seiring berkembangnya semua aspek dalam kehidupan, berkembang pula bermacam resiko yang berasal dari dalam maupun dari luar organisasi (perusahaan) yaitu banyaknya pesaing, maka audit internal dimungkinkan berperan serta menentukan tujuan dari perusahaan tersebut. Proses auditnya disebut quality assurance dan bersifat jangka panjang karena ikut menanamkan nilai-nilai yang sangat mendasar sesuai konsep quality management yang menjadi pegangan karyawan.

\section{Peran auditor internal sebagai audit snoop}

Penelitian yang dilakukan oleh Listiatik (2007) menyebutkan bahwa peran auditor internal menimbulkan perbedaan persepsi karyawan Rumah Sakit Panti Rini. Ada beberapa karyawan memiliki persepsi bahwa auditor internal sebagai kawan karena menganggap dengan keberadaan auditor internal sebagai konsultan dan katalisator yang dapat memberikan kontribusi berupa saran atau masukan dalam pencapaian tujuan perusahaan. Di sisi lain, ada sebagian karyawan yang memiliki persepsi bahwa auditor internal adalah lawan karena melihat peran sebagai pengawas yang dijalankan auditor internal seperti layaknya polisi yang melakukan pemeriksaan.

Begitupun penelitian yang dilakukan oleh Priantinah dkk (2012) persepsi karyawan tentang peran auditor internal sebagai pengawas, konsultan dan katalisator Dalam pencapaian tujuan perusahaan studi kasus di hotel inna garuda Yogyakarta di Hotel Inna Garuda Yogyakarta yang menunjukkan bahwa terdapat perbedaan persepsi atas peran auditor internal, yang paling berperan adalah sebagai Pengawas. Oleh karena itu dirumuskan hipotesis sebagai berikut:

$\mathrm{Ho}_{1}$ : Tidak terdapat perbedaan persepsi antara pegawai tenaga pendidik dan pegawai kependidikan atas peran auditor internal sebagai audit snoop di BLU Universitas Bengkulu

\section{Peran audit internal sebagai consultant}

Penelitian terdahulu yang dilakukan oleh Tjahyono (2010) mengenai analisis peran auditor internal di Perguruan Tinggi Swasta Universitas Sanata Dharma menunjukkan bahwa terdapat perbedaan persepsi atas peran auditor internal, yang paling berperan adalah sebagai Consultant. Penelitian yang dilakukan oleh Krisna (2016) mengenai persepsi karyawan pada unit auditor internal di RSUP Dr. Soeradji Tirtonegoro Klaten menyimpulakan bahwa terdapat perbedaan persepsi antara karyawan dimana peran sebagai Consultant yang mendapat peringkat pertama.

Penelitian Sugiarti (2015) mengenai persepsi peran auditor internal di PT.XYZ menyimpulkan bahwa tidak ditemukan perbedaan persepsi yang signifikan antara auditor internal dan auditee terhadap aktivitas audit internal. Kesamaan persepsi antara auditor 
internal dan auditee tersebut merupakan salah satu faktor yang menyebabkan aktivitas audit internal berjalan dengan efektif. Oleh karena itu dirumuskan hipotesis sebagai berikut:

$\mathrm{Ho}_{2}$ : Tidak terdapat perbedaan persepsi antara pegawai tenaga pendidik dan pegawai kependidikan atas peran auditor internal sebagai consultant di BLU Universitas Bengkulu.

\section{Peran audit internal sebagai management's representative}

Berdasarkan hasil penelitian menurut Citriadi (2015) terdapat perbedaan persepsi antara karyawan. Peran auditor sebagai pengawas mendapatkan frekuensi sebesar $67,1 \%$, sedangkan untuk peran auditor internal sebagai konsultan mendapat frekuensi sebesar 79,3\%, dan untuk peran auditor sebagai katalisator mendapat frekuensi sebasar 82,9\%. Jadi, dapat disimpulkan bahwa persepsi auditee mengindikasikan bahwa peran auditor internal dalam bidang perbankan sudah cukup efektif dalam pelaksanaannya. Begitupun penelitian yang dilakukan oleh Budiman (2015) mengenai persepsi manajer perusahaan terhadap fungsi audit internal yang bernilai tambah menyimpulkan bahwa terdapat perbedaan persepsi, sebagian besar responden setuju bahwa auditor internal yang ada diperusahaannya mampu memberikan aktivitas bernilai tambah untuk membantu perusahaan dalam mencapai tujuannya tidak hanya berperan sebagai pengawas yang hanya mencari-mencari masalah dari perusahaan.

Ho3 : Tidak terdapat perbedaan persepsi antara pegawai tenaga pendidik dan pegawai kependidikan atas peran auditor internal sebagai management's representative di BLU Universitas Bengkulu

\section{METODE PENELITIAN}

\section{Populasi Dan Sampel Penelitian}

Populasi dalam penelitian ini adalah seluruh pegawai Aparatur Sipil Negara dan pegawai honorer yang ada di Universitas Bengkulu. Yang menjadi sampel dalam penelitian ini adalah pegawai tenaga pendidik dan kependidikan. Teknik pengambilan sampel dalam penelitian ini adalah menggunakan Purposive Sampling, yaitu pengambilan sampel yang bersifat tidak acak, yang dipilih berdasarkan kriteria tertentu. Adapun kriteria sampel adalah sebagai berikut. Kelompok 1 adalah Pegawai Tenaga Pendidik yang merupakan pegawai Aparatur Sipil Negara dengan tugas tambahan seperti Dekan, wakil Dekan, dan Ketua Jurusan atau prodi S1 di Universitas Bengkulu. Kelompok 2adalah Pegawai Kependidikan yang merupakan pegawai Aparatur Sipil Negara dan pegawai non pns yang ada di bagian keuangan Universitas Bengkulu.

\section{Variabel Penelitian, Defenisi Operasional dan Pengukuran Variabel}

Dari variabel yang telah digambarkan pada kerangka pemikiran dalam penelitian ini, definisi operasional yang digunakan adalah sebagai berikut.

1. Peran auditor sebagai audit snoop; Peran audit snoop bertujuan untuk memastikan ketaatan atau kepatuhan terhadap ketentuan, peraturan atau kebijakan yang telah ditetapkan. Audit yang dilakukan adalah compliance audit dan apabila terdapat penyimpangan dapat dilakukan koreksi terhadap sistem pengendalian manajemen. Peran audit snoop biasanya menghasilkan saran atau rekomendasi yang mempunyai impact jangka pendek, misalnya perbaikan sistem dan prosedur atau internal control.

2. Peran auditor sebagai consultant; Peran sebagai consultant diharapkan dapat memberikan manfaat berupa nasehat dalam pengelolaan sumber daya organisasi sehingga dapat membantu tugas para manajer operasional. audit yang dilakukan adalah operational audit 
atau performa audit, yaitu meyakinkan bahwa organisasi telah memanfaatkan sumber daya organisasi secara ekonomis, efisien dan efektif sehingga dapat dinilai apakah manajemen telah menjalankan aktivitas organisasi yang mengarah pada tujuannya.

3. Peran auditor sebagai management's representative; Peran auditor internal sebagai management's representative berkaitan dengan quality assurance, sehingga auditor internal diharapkan dapat membimbing manajemen dalam mengenali risiko-risiko yang mengancam pencapaian tujuan organisasi. Quality assurance bertujuan untuk meyakinkan bahwa proses bisnis yang dijalankan telah menghasilkan produk atau jasa yang dapat memenuhi kebutuhan customer. Dalam peran management's representative, auditor internal bertindak sebagai fasilitator dan agent of change. Impact dari peran management's representative bersifat jangka panjang, karena fokus katalis adalah nilai jangka panjang dari organisasi, terutama berkaitan dengan tujuan organisasi yang dapat memenuhi kepuasan stakeholder. Penerapan risk management dan risk based audit adalah salah satu contoh peran auditor internal sebagai management's representative.

\section{Metode Analisis Data}

\section{Uji Kualitas Data}

Menurut Ghozali (2006), kualitas data yang dihasilkan dari penggunaan instrumen penelitian dapat dievaluasi melalui uji reliabilitas dan uji validitas. Pengujian tersebut masingmasing untuk mengetahui konsistensi dan akurasi data yang dikumpulkan dari penggunaan instrumen.

\section{Uji Validitas}

Uji validitas data digunakan untuk mengukur sah atau valid tidaknya suatu kuesioner. Suatu kuesioner dikatakan valid jika pertanyaan pada kuesioner mampu untuk mengungkapkan sesuatu yang akan diukur oleh kuesioner tersebut. Uji validitas yang digunakan dalam menghitung korelasi antara skor masing-masing butir pertanyaan dengan tata skor setiap konstruknya (Ghozali, 2006). Pengujian ini menggunakan metode pearson correlation. Untuk melihat tingkat validitas digunakan taraf signifikan 5\%. Kriteria yang diterapkan dalam menentukan validitas data adalah dengan melihat signifikansi $\mathrm{r}$ hitung (koefisien dan korelasi) pada taraf signifkansi 5\%. Dikatakan valid apabila korelasi antar skor masing-masing butir pertanyaan dengan total skor setiap konstruknya berbeda pada level di bawah 5\%, sehingga alat ukur dinyatakan valid jika nilai signifikansinya $<0,05$ (Ghozali, 2006).

\section{Uji Reliabilitas}

Pengujian reliabilitas dimaksudkan untuk mengukur bahwa instrumen yang digunakan benar-benar menghasilkan data yang bebas dari kesalahan. Suatu instrumen dikatakan reliabel jika jawaban terhadap pertanyaan adalah konsisten dari waktu ke waktu. Teknik yang digunakan untuk mengukur reliabilitas dengan menggunakan cronbach's alpha. Variabel tersebut akan dikatakan reliabel bila cronbach alpha-nya memiliki nilai lebih besar dari 0,60 (Ghozali, 2006).

\section{Uji Normalitas}

Uji normalitas bertujuan untuk menguji apakah dalam model regresi, variabel pengganggu atau residual memiliki distribusi normal. Uji normalitas ini digunakan untuk semua hipotesis. Ada dua cara untuk mendeteksi apakah residual berdistribusi normal atau tidak yaitu dengan analisis grafik dan uji statistik. Pengujian normalitas data dengan analisis 
statistik salah satunya dilakukan dengan menggunakan uji statistik non-parametric kolmogorov-smirnov (K-S).

\section{HASIL DAN PEMBAHASAN}

\section{Deskriptif Data Penelitian}

Sampel dalam penelitian ini adalah pegawai tenaga pendidik yang mempunyai tugas tambahan, dan pegawai tenaga kependidikan yang bekerja di bagian keuangan. Pegawai tenaga pendidik yang menjadi responden dalam penelitian ini terdiri dari Dekan, wakil Dekan, Ketua Jurusan atau Ketua Prodi yang berjumlah keseluruhan 74 responden. Sedangkan tenaga kependidikan yang menjadi responden dalam penelitian ini adalah seluruh pegawai tetap dan pegawai tidak tetap yang bekerja di bagian keuangan rektorat dan fakultas-fakultas yang berjumlah keseluruhan 60 responden. Sampel penelitian ini terdiri dari 74 responden tenaga pendidik dan 60 responden tenaga kependidikan disajikan dalam tabel berikut :

Tabel 1. Sampel Penelitian

\begin{tabular}{l|c|c}
\hline \multicolumn{1}{c|}{ Unit/Fakultas/Subbag } & $\begin{array}{c}\text { Pegawai Tenaga } \\
\text { Pendidik }\end{array}$ & $\begin{array}{c}\text { Pegawai Tenaga } \\
\text { Kependidikan }\end{array}$ \\
\hline Bagian Rektorat & - & 20 \\
\hline $\begin{array}{l}\text { Fakultas Keguruan dan Ilmu } \\
\text { Pendidikan }\end{array}$ & 16 & 8 \\
\hline Fakultas Hukum & 7 & 4 \\
\hline Fakultas Ekonomi dan Bisnis & 7 & 5 \\
\hline Fakultas Ilmu Sosial Dan Ilmu Politik & 11 & 5 \\
\hline Fakultas Pertanian & 12 & 2 \\
\hline Fakultas Matematika dan Ilmu & 8 & 3 \\
Pengetahuan Alam & & 4 \\
\hline Fakultas Teknik & 8 & $\mathbf{6 0}$ \\
\hline Fakultas Kedokteran & 5 & $\mathbf{7 4}$ \\
\hline \multicolumn{1}{c}{ Total } &
\end{tabular}

\section{Statistik Deskriptif}

Statistik deskriptif dalam penelitian ini disajikan pada Tabel berikut :

Tabel 2. Statistik Deskriptif Pegawai Tenaga Pendidik

\begin{tabular}{c|c|c|c|c|c|c|c}
\hline \multirow{2}{*}{ Variabel } & \multicolumn{2}{|c|}{$\begin{array}{c}\text { Kisaran } \\
\text { Teoritis }\end{array}$} & \multirow{2}{*}{$\begin{array}{c}\text { Mean } \\
\text { Teoritis }\end{array}$} & \multicolumn{2}{|c|}{$\begin{array}{c}\text { Kisaran } \\
\text { Aktual }\end{array}$} & \multirow{2}{*}{$\begin{array}{c}\text { Mean } \\
\text { Aktual }\end{array}$} & $\begin{array}{c}\text { Standar } \\
\text { Deviasi }\end{array}$ \\
\cline { 2 - 6 } & Min & Max & & Min & Max & & \\
\hline AS & 8 & 40 & 24 & 20 & 35 & 27,45 & 3,605 \\
\hline CS & 8 & 40 & 24 & 19 & 39 & 31,32 & 3,929 \\
\hline MR & 8 & 40 & 24 & 21 & 39 & 31,15 & 4,282 \\
\hline
\end{tabular}


Tabel 3. Statistik Deskriptif Pegawai Tenaga Kependidikan

\begin{tabular}{l|c|c|c|c|c|c|c}
\hline \multirow{2}{*}{ Variabel } & \multicolumn{2}{|c|}{$\begin{array}{c}\text { Kisaran } \\
\text { Teoritis }\end{array}$} & \multirow{2}{*}{$\begin{array}{c}\text { Mean } \\
\text { Teoritis }\end{array}$} & \multicolumn{2}{|c|}{$\begin{array}{c}\text { Kisaran } \\
\text { Aktual }\end{array}$} & \multirow{2}{*}{$\begin{array}{c}\text { Mean } \\
\text { Aktual }\end{array}$} & \multirow{2}{*}{$\begin{array}{c}\text { Standar } \\
\text { Deviasi }\end{array}$} \\
\cline { 2 - 3 } \cline { 5 - 6 } & Min & Max & & Min & Max & & \\
\hline AS & 8 & 40 & 24 & 18 & 35 & 27,64 & 3,874 \\
\hline CS & 8 & 40 & 24 & 19 & 40 & 31,58 & 4,293 \\
\hline MR & 8 & 40 & 24 & 19 & 39 & 31,18 & 5,078 \\
\hline
\end{tabular}

\section{Hasil Pengujian Hipotesis}

Untuk menguji hipotesis pertama, kedua, dan ketiga peneliti menggunakan independent sample t test. Hasil pengujian hipotesis tersebut disajikan dalam Tabel berikut ini :

Tabel 4. Hasil Pengujian Hipotesis 1, 2, dan 3

\begin{tabular}{c|c|c|c}
\hline Keterangan & Sig Levene's Test & t tabel & Signifikan \\
\hline AS1-AS2 & 0,000 & $-0,7927$ & 0,000 \\
\hline CS1-CS2 & 0,401 & 10,375 & 0,000 \\
\hline MR1-MR2 & 0,920 & $-0,474$ & 0,637 \\
\hline
\end{tabular}

Hasil uji beda pada tabel 3 diatas menunjukkan nilai signifikan dengan masing masing variabel pegawai tenaga pendidik dan pegawai tenaga kependidikan. Untuk variabel audit snoop, dapat dilihat nilai signifikannya sebesar 0,000 . Nilai ini sesuai dengan kriteria pvalue $<0,05$. Artinya hipotesis $\mathrm{H}_{01}$ ditolak, yang berarti terdapat perbedaan persepsi atas peran auditor internal yang diproksikan dengan audit snoop antara pegawai tenaga pendidik dan pegawai tenaga kependidikan.

Untuk variabel consultant nilai signifikan sebesar 0,000. Sama halnya dengan variabel audit snoop, nilai signifikan variabel consultant juga sesuai dengan kriteria p-value $<0,05$. Artinya hipotesis $\mathrm{H}_{02}$ ditolak, yang berarti terdapat perbedaan persepsi atas peran auditor internal yang diproksikan dengan consultant antara pegawai tenaga pendidik dan pegawai tenaga kependidikan.

Untuk variabel management representative's nilai signifikan sebesar 0,637. Berbeda dengan variabel-variabel sebelumnya, variabel management representative's memiliki nilai signifikan yang lebih besar dari 0,05 . Nilai ini sesuai dengan kriteria p-value $\geq 0,05$. Artinya hipotesis $\mathrm{H}_{03}$ diterima, yang berarti tidak terdapat perbedaan persepsi atas peran auditor internal yang diproksikan dengan management representative's antara pegawai tenaga pendidik dan pegawai tenaga kependidikan.

\section{Pembahasan}

Pengujian pertama pada hipotesis $\mathrm{H}_{\mathrm{o} 1}$ bertujuan untuk membuktikan apakah terdapat perbedaan persepsi pegawai tenaga pendidik dan pegawai tenaga kependidikan atas peran auditor internal di Universitas Bengkulu. Peran auditor internal ini diproksikan dengan audit snoop. Hasil pengujian yang dilakukan menunjukkan terdapat perbedaan persepsi mengenai peran audit internal sebagai audit snoop pegawai tenaga pendidik dan pegawai tenaga 
kependidikan di Universitas Bengkulu. Perbedaan persepsi ini menunjukkan bahwa pegawai tenaga pendidik dan pegawai tenaga kependidikan dibekali pengetahuan dan pengalaman yang berbeda sehingga menimbulkan pandangan yang berbeda pula terhadap peran audit internal sebagai audit snoop. Peran auditor internal sebagai audit snoop menurut persepsi pegawai tenaga pendidik maupun pegawai tenaga kependidikan menempati peringkat ketiga sebagai peran audit internal yang sangat berperan di Universitas Bengkulu dengan nilai ratarata 27,45 dan 27,64 .

Hasil penelitian ini sesuai dengan penelitian yang dilakukan Tjahyono (2010) yang menyatakan bahwa peran audit sebagai audit snoop menempati peringkat ketiga di perguruan tinggi swasta Universitas Sanata Dharma. Pengujian kedua pada hipotesis $\mathrm{H}_{\mathrm{o} 2}$ bertujuan untuk membuktikan apakah terdapat perbedaan persepsi pegawai tenaga pendidik dan pegawai tenaga kependidikan atas peran auditor internal di Universitas Bengkulu. Peran audit internal ini diproksikan dengan consultant. Hasil pengujian yang dilakukan menunjukkan terdapat perbedaan persepsi mengenai peran audit sebagai consultant menurut pegawai tenaga pendidik dan pegawai tenaga kependidikan di Universitas Bengkulu. Perbedaan persepsi ini menunjukkan bahwa pegawai tenaga pendidik dan pegawai tenaga kependidikan dibekali pengetahuan dan pengalaman yang berbeda sehingga menimbulkan pandangan yang berbeda pula terhadap peran audit internal sebagai consultant.

Peran auditor internal sebagai consultant menurut persepsi pegawai tenaga pendidik maupun pegawai tenaga kependidikan menempati peringkat pertama sebagai peran audit internal yang sangat berperan di Universitas Bengkulu dengan nilai rata-rata 31,32 dan 31,58. Hasil penelitian ini sesuai dengan penelitian yang dilakukan Tjahyono, (2010) yang menyatakan bahwa peran audit sebagai consultant menempati peringkat pertama di perguruan tinggi swasta Universitas Sanata Dharma.

Pengujian kedua pada hipotesis $\mathrm{H}_{03}$ bertujuan untuk membuktikan apakah terdapat perbedaan persepsi pegawai tenaga pendidik dan pegawai tenaga kependidikan atas peran auditor internal di Universitas Bengkulu. Peran audit internal ini diproksikan dengan management's representative. Hasil pengujian yang dilakukan menunjukkan tidak terdapat perbedaan persepsi mengenai peran audit sebagai management's representative menurut pegawai tenaga pendidik dan pegawai tenaga kependidikan di Universitas Bengkulu.

Peran auditor internal sebagai management's representative menurut persepsi pegawai tenaga pendidik maupun pegawai tenaga kependidikan menempati peringkat kedua sebagai peran audit internal yang sangat berperan di Universitas Bengkulu dengan nilai rata-rata 31,15 dan 31,18. Hasil penelitian ini tidak sesuai dengan penelitian yang dilakukan Priantinah dkk (2012) yang menyatakan bahwa peran audit sebagai management's representative menempati peringkat ketiga dalam pencapaian tujuan perusahaan.

\section{SIMPULAN}

Peran auditor internal dalam sebuah organisasi, seharusnya dan idealnya dipersepsikan sama oleh seluruh anggota organisasi. Jika terdapat perbedaan, maka peran auditor internal belum sepenuhnya dipahami oleh seluruh anggota organisasi.

Hasil penelitian ini menunjukkan bahwa masih terdapat perbedaan persepsi antara tenaga pendidik dan tenaga pendidik atas peran internal auditor di universitas Bengkulu. Untuk mencapai pemahaman yang sama, maka dibutuhkan upaya dari manajemen dan unit audit internal untuk memberikan informasi dan sosialisasi sehingga setiap anggota organisasi memahami peran auditor internal. 


\section{Implikasi Penelitian}

Hasil penelitian tentang budaya organisasi, konflik peran serta ambiguitas terhadap akuntabilitas publik yang dimoderasi oleh komitmen organisasi di Universitas Bengkulu ini mempunyai implikasi sebagai berikut:

1. Dapat menjadi pertimbangan Pimpinan Universitas Bengkulu untuk meningkatkan peran audit internal sebagai audit snoop sehingga dapat memberikan kontribusi yang maksimal dalam membantu pencapaian tujuan organisasi.

2. Dapat menjadi pertimbangan bagi Universitas Bengkulu untuk lebih memperhatikan dan memaksimalkan kegiatan audit internal dengan peran sebagai consultant sehingga dapat memberikan masukan dan pemikiran dalam membantu pencapaian organisasi serta dapat menunjang efektivitas pengendalian atas kegiatan-kegiatan yang berjalan di Universitas Bengkulu.

3. Hasil penelitian ini diharapkan bisa membantu dalam memberikan masukan bagi Universitas Bengkulu dalam menentukan tujuan organisasi dengan memaksimalkan kinerja peran audit internal sebagai Management's Representative walaupun dalam menerapkan peran ini secara penuh membutuhkan waktu yang cukup panjang.

4. Hasil penelitian ini dapat menjadi referensi bagi peneliti selanjutnya yang tertarik meneliti dan mengkaji permasalahan yang sama, sehingga dapat memperkaya ilmu pengetahuan.

\section{Keterbatasan Penelitian}

Penelitian selanjutnya dapat menambah data dari hasil wawancara mendalam (metode triangulation) dan memperluas sampel penelitian.

\section{DAFTAR PUSTAKA}

Arens, A. Alvin, Loebbecke, James. K, 2011. Auditing: Pendekatan Terpadu. (Alih Bahasa Yusuf, Amir Abadi) Edisi I. Jakarta: Salemba Empat.

Budiman, S. T., 2015. Persepsi Manajer Perusahaan Terhadap Fungsi Audit Internal yang Bernilai Tambah. Skripsi. Tidak dipublikasikan. Universitas Katolik Widya Mandala. Surabaya.

Citriadi, Andi Sederajat (2015). Persepsi Auditee terhadap Peran Auditor Internal dalam Pencapaian Tujuan Organisasi (studi kasus pada pt bank sulselbar). Skripsi. Tidak dipublikasikan. Universitas Hasanuddin. Makassar.

Ghozali, I., 2006. Aplikasi Analisis Multivariate dengan Program SPSS, Badan Penerbit Universitas Diponegoro, Semarang.

Halim, A., 1992. Hubungan Koordinasi Antara Auditing Eksternal dan Internal, Jurnal Akuntansi dan Manajemen, Edisi Oktober 1992.

Ikhsan, A. dan Ishak, M., 2005. Akuntansi Keprilakuan. Salemba Empat: Jakarta.

Kreitner, R., dan Kinicki., A., 2003. Perilaku organisasi (Organizational Behaviour). Jakarta: Salemba Empat.

Krisna, L.W., 2016. Persepsi Karyawan pada Unit Auditor Internal (Sstudi Kasus di RSUP Dr. Soeradji Tirtonegoro Klaten). Tidak dipublikasikan. Skripsi. Universitas Sanata Dharma. Yogyakarta 
Listiatik. 2007. Persepsi Keryawan Tentang Auditor Internal pada Rumah Sakit Panti Rapih. Skripsi. Tidak dipublikasikan. Universitas Sanata Dharma.Yogyakarta.

Mulyadi. 2013. Auditing, Buku Satu. Jakarta : Salemba Empat.

Priantinah, D dan Adhisty, M.C., 2012. Persepsi karyawan tentang peran auditor internal sebagai pengawas, konsultan dan katalisator dalam pencapaian tujuan perusahaan. Skripsi. Tidak dipublikasikan. Universitas Negeri Yogyakarta.

Robbins, S.P., 2008. Perilaku Organisasi, Edisi Kesepuluh. Diterjemahkan oleh Diana Angelina. Jakarta: Salemba Empat.

Ronald, D.R., 2006. Peranan Audit Internal pada PT. General electric Indonesia. Skripsi. Tidak dipublikasikan. Universitas Sanata Dharma.

Sawyer, L.B., 2005. Internal Auditing. Edisi 5. Jakarta: Salemba Empat.

Suharnan. 2005. Psikologi Kognitif. Surabaya: Srikandi.

Sunaryo. 2004. Psikologi untuk Keperawatan. Jakarta: Penerbit buku kedokteran EGC. (http://books.google.co.id). Diakses pada 20 November 2015.

Tampubolon, R., 2005. Risk and System-Based Internal Audit. Jakarta: Elex Media Komputindo.

Tjahyono, B., 2010. Analisis Peran Auditor Internal di Perguruan Tinggi Swasta Universitas Sanata Dharma. Skripsi. Tidak dipublikasikan. Universitas Sanata Dharma. Yogyakarta. 